\title{
The Use of Plants and Wildflowers as Bioremediation for Contaminated Soils in the Hong Kong S.A.R.
}

\author{
Angelo Indelicato \\ Dragages Hong Kong Ltd., Hong Kong, China \\ Email: angelo.indelicato@dragageshk.com
}

Received 25 July 2014; revised 22 August 2014; accepted 4 September 2014

Copyright (C) 2014 by author and Scientific Research Publishing Inc.

This work is licensed under the Creative Commons Attribution International License (CC BY).

http://creativecommons.org/licenses/by/4.0/

(c) (i) Open Access

\begin{abstract}
Heavy metal contamination of the biosphere has increased sharply over the last century. Anthropogenic activities such as industrialisation and demographic growth can be considered as the main causes of it. Soil contamination affects every organism and poses major environmental and human health problems worldwide. The issue has been addressed in the past and a few methodologies have been developed in order to effectively clean up the contaminated areas. However, many of these remedies are very aggressive and can damage the soil. This paper focuses on the use of gentler techniques, which take advantage of the properties of several plants and wildflowers that absorb heavy metals and polycyclic aromatic hydrocarbons, and their potential application in megacities such as Hong Kong.
\end{abstract}

\section{Keywords}

Hong Kong, Bioremediation, Wildflowers, Contaminated Land

\section{Introduction}

Hong Kong (Figure 1) is located at the south-eastern tip of the Chinese mainland. With a population of over 7 million inhabitants and a total area of approximately $1100 \mathrm{~km}^{2}$, it is one of the most densely populated cities in the world. The rapid economic and demographic growth in the region during the last few decades has had a significant environmental impact. Hong Kong's mountainous landscape and limited flat land compresses much of the residential and commercial activities on the hillsides and in the coastal areas surrounding Victoria Harbour. These estates are located close to roads and highways, making them susceptible to various sources of pollution.

Urban soil is remarkably contaminated by heavy metals and other pollutants. Elevated concentrations of 


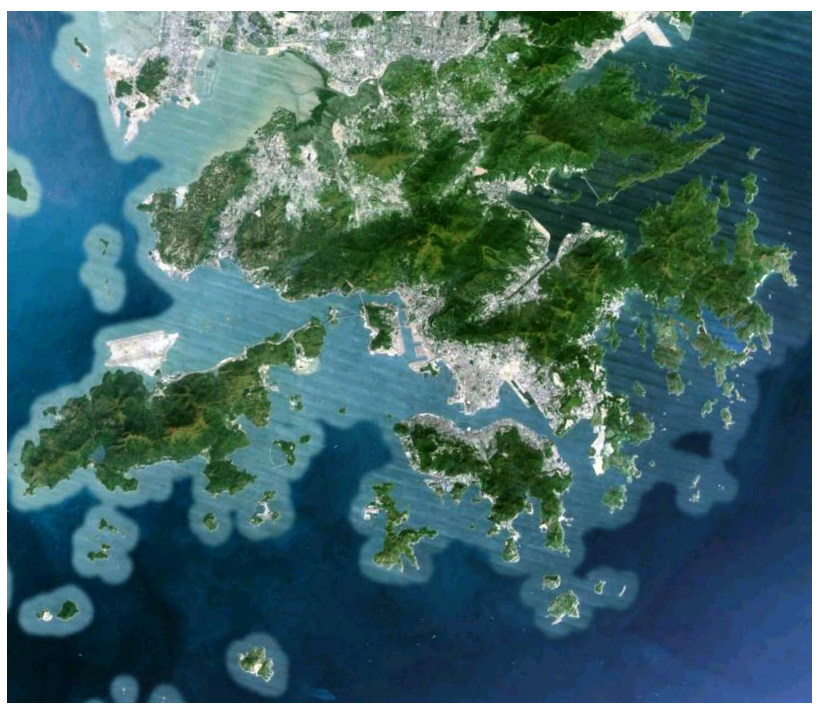

Figure 1. Hong Kong ( ${ }^{\oplus}$ Google Earth 2014).

heavy metals are known to have an adverse effect on human health, especially on that of children, as they have a high absorption rate due to their active digestion and sensitivity to haemoglobin [1]. According to a survey conducted in 1981 by Lau and Wong, the highest amount of Cadmium $(54 \mathrm{mg} / \mathrm{kg}$ ) was found in a recreational park, and the highest amount of Copper $(205 \mathrm{mg} / \mathrm{kg})$ was identified in an industrial estate in Aberdeen.

Rural expanses are also subject to soil contamination. To ease the densely populated centre, the so-called "satellite" cities in the New Territories have been developed and expanded so now housing estates are interspersed with agricultural and industrial areas. The highest concentration of Lead and Zinc, $229 \mathrm{mg} / \mathrm{kg}$ and $259 \mathrm{mg} / \mathrm{kg}$ respectively, were found in the agricultural area of Man Uk Pin [1].

Pollution in Hong Kong not only accumulates in Kowloon and around Victoria Harbour but it affects every part of the city and its surroundings. As the concentration of these pollutants increases, it is vital to find new methods to clean the soil and the water. This study will focus on effective bioremediation treatments to soil pollution.

\section{Soil Composition}

Soil is a complex mixture of organic and inorganic material. The organic components derive from the decayed remains of plants and animals [2]. The inorganic parts are made of rock fragments that were formed by bedrock weathering over thousands of years.

Typical soils are made of several main layers, or horizons. The uppermost (topsoil) is humus-rich and comprises of decaying organisms, microorganisms, insects and worms. Below this layer lies the subsoil, created predominated by inorganic particles, minerals and organic substances leached from the horizon above. The deepest horizon consists of fragmented bedrock mixed within a matrix of silt, sand and clay, also known as saprolitic soil.

Organic matter and anthropogenic compounds such as pesticides and their degradation products can react with humus. Water-soluble humus, like fulvic acid, can form complexes with organic pesticides at the soil surface. Percolating water can transport these compounds deep into the soil.

Soil is an innate transmitter of pollutants to surface water, groundwater, the atmosphere and food, thus posing a substantial threat to human life. When air and water are polluted, switching off the source of pollution, followed by dilution and self-purification, can reverse the problem. However, these techniques cannot be used to eliminate heavy metal contamination in the soil, making remediation expensive and time-consuming [3].

In Hong Kong, above the saprolite lie two deposits from the Pleistocene. The Middle Pleistocene Colluvial Deposit (Po Chu Tam Formation) is stiff to very stiff, slightly clayey sandy silt with $30 \%$ to $70 \%$ highly to completely decomposed sub-angular to sub-rounded cobbles and boulders [4]. A similar composition is also found in the Late Pleistocene Colluvial Deposits (Shum Wan Formation).

Two deposits from the Holocene have been identified: the colluvial and alluvial deposits. The colluvial depo- 
sit is soft to firm clayey sandy silt to silty fine sand with angular to sub-angular gravel and cobbles. The latter (Fan Ling Formation), occurring mainly along the course of narrow streams, is made of clayey silty sand with a thin layer of organic mud [4].

The urban soil has undertaken drastic modification due to burial, mixing, truncation or wholesale removal. Contamination by building debris is common, with cement, mortar, concrete and occasional brick fragments and other inert foreign materials [5]. There is no organic-matter rich topsoil and the release of alkaline leachate from calcareous construction wastes can raise the $\mathrm{pH}$ level beyond the normal tolerance [5].

\section{Types of Contaminants Present in the Soil}

Contaminants present in the soil can be quite different. Heavy metal contamination refers to the excessive deposition of toxic heavy metals in the soil caused by human activity. Some examples of metals with significant biological toxicity are Mercury (Hg), Cadmium (Cd), Lead (Pb), Chromium (Cr) and Arsenic (As). Other heavy metals like Zinc (Zn), Copper (Cu), Nickel (Ni) and so on [3], are also present. With the exception of Cu and Cd, most of heavy metal contamination is both colourless and odourless and it does not explicitly damage the environment in the short term. However, when it exceeds environmental tolerance, heavy metals in the soil can be activated and cause serious ecological damage [3].

Atmospheric deposition, sewage irrigation, improper stacking of industrial solid waste, use of pesticides and fertilizers, and so on, are among the many sources of soil contamination. Heavy metals in the atmosphere, on the other hand, are mainly from gas and dust produced by energy and transport, with burning leaded gasoline and the dust produced by automobile tyre wear as the leading causes. In a city like Hong Kong plagued with extreme traffic congestion, high-rise buildings form a man-made canyon landscape where the dust collects at the bottom and the wind has zero to slim chances of clearing it up, thus aggravating this pollution. Areas such as Mongkok and Prince Edward have more serious concentrations of $\mathrm{Pb}$ than others and, considering the amount of people living there, many are exposed to toxic gases on a daily basis, with debilitating consequences to their health. Heavy metal pollutants tend to persist in the soil, although impermeable concrete paving can stop and even seal water infiltration and prevent the soil from otherwise leaching and spreading the pollutants [5]. Another main source comes from energy production, such as thermal power stations that produce coal ashes (containing Cd, $\mathrm{Cu}, \mathrm{Pb}$ and $\mathrm{Zn}$ ), which are dispersed on land and at sea. Animal waste, spent litter and compost which may contain high levels of trace-metals such as $\mathrm{Cu}$ and $\mathrm{Zn}$, are traditionally used in local farms and can also contribute to soil contamination [6].

Inorganic forms of As were once used extensively as agricultural pesticides and high concentrations of Lead are due to the heavy use of $\mathrm{Pb}$-containing agrochemicals. Agricultural wastes are among the most serious causes of pollution in Hong Kong. Pig effluents and poultry droppings highly contribute to the total quantity of readily putrescible matter entering the streams but also in the soil as it is used as fertilizer. It contains substantial amount of $\mathrm{Pb}, \mathrm{Cu}, \mathrm{Zn}$ and $\mathrm{Mn}$ [7].

E-waste recycling activities, including dismantling and open burning, have generated a large amount of heavy metals and persistent toxic substances on existing abandoned farm soils in Hong Kong [9].

Other very noxious substances that can be found in soil are polycyclic aromatic hydrocarbons (PAHs). They are very toxic to many living organisms and with reluctance to degradation and high lipophilicity; they form a class of very dangerous compounds [8].

Polycyclic aromatic hydrocarbons (PAHs) are usually produced via the incomplete combustion of organic substances and are comprised of a diverse group of organic compounds [9].

Among hydrocarbon pollutants, diesel oil is a complex mixture of alkanes and aromatic compounds that are frequently reported as soil contaminants leaking from storage tanks and pipelines or released in accidental spills.

\section{Remediation Techniques Used in Hong Kong}

According to the Environmental Protection Department [10] various remediation methods have been historically applied to contaminated soils in Hong Kong.

Biopiles involve heaping contaminated soils into piles and stimulating aerobic microbial activity within the soils through aeration and/or the addition of minerals, nutrients and moisture. This technique may not be effective for high levels of contaminants.

Soil Vapour Extraction removes vapours from soil above the water table by applying a vacuum to pull out the 
contaminated rich vapours. It is very effective in treating volatile organic compounds (VOC). However, elevated organic content or extremely dry soils have a high absorption of VOCs, which result in a reduced removal rate.

Stabilisation/solidification traps or immobilises contaminants within the host soil. It is the only method of remediation used to adequately treat heavy metal contamination. However it does not trap organics and has depth limitations. Its long-term effectiveness has also not been demonstrated.

Thermal desorption heats the contaminants within the soil until they vaporise into gas that is subsequently collected and treated. The results have different degrees of effectiveness.

\section{Commonly-Used Bioremediation}

One of the best approaches to restoring contaminated soil is the use of microorganisms capable of degrading toxic compounds in a bioremediation process [11]. This system is used to clean up petroleum hydrocarbons. Diesel oil contamination in soils can also be promoted by stimulating the indigenous microorganisms; by introducing nutrients and oxygen into the soils in a process called biostimulation or through the inoculation of an enriched microbial consortium into said soils (bioaugmentation). In Hong Kong, microorganisms are currently used in biopiles.

Microbial remediation can also be used successfully as some microorganisms absorb, precipitate, oxidise and reduce heavy metals in soils [3].

Furthermore, maggots and earthworms living underground can take heavy metals in the soil, though they may only absorb a select amount of contaminants.

Microbial bioremediation has been successful for the degradation of certain organic contaminants, but is ineffective in addressing the challenge of toxic metal contamination [12]. Toxic metals can only be remediated by their removal from soil.

A new cost-effective "green" technology known as phytoremediation involves the use of particular types of plants capable of hyper-accumulating contaminants in the ground.

There are various types of phytoremediation:

1) Phytoextraction known as phytoaccumulation or phytoabsorption. This process came from the discovery of a variety of wild plants that concentrate high amounts of essential and non-essential heavy metals in their foliage. The degree of accumulation of metals such as $\mathrm{Zn}, \mathrm{Ni}$, and possibly $\mathrm{Cu}$ often reaches $1 \%$ - $5 \%$ of the dry weight [12]. $\mathrm{Pb}$ is extremely insoluble and not generally available for plants to uptake in the normal range of soil $\mathrm{pH}$. To acquire these soil-bound metals, phytoextracting plants have to mobilise them into the soil solution. This can be accomplished in different ways, from metal chelating molecules to acidifying the soil with protons extruded from the roots. However, this is also very dangerous as these chelating molecules increase the solubility of metals within the soil [13].

2) Phytodegradation, where plants take up and break down contaminants through the release of enzyme and metabolic processes such as photosynthetic oxidation and reduction. In this process organic pollutants are degraded and incorporated into the plant or broken down in the soil.

3) Phytovolatilisation, in which plants take up volatile contaminants and following transpiration, release non-toxic substances into the atmosphere.

4) Phytostabilisation, in which some plants can sequester or immobilise contaminants. This method limits the movements of contaminants through erosion, leaching and wind or soil dispersal.

5) Rhizodegradation, where the roots of some plants assist in the microbial degradation of contaminants.

\section{The Use of Plants and Wildflowers as Bioremediation}

An abundance of plants and flowers can be used to clean up contaminated soil. In one particular family of plants (Brassicaceae), there are several that work well as accumulators and hyper-accumulators. Mustard (Brassica juncea Linn.) soaks up heavy metals such as $\mathrm{Cr}, \mathrm{Ni}, \mathrm{Pb}, \mathrm{U}$ and $\mathrm{Zn}$ and it also acts as a hyper-accumulator for $\mathrm{Cu}$ [14].

A group of plants from different families share the characteristics of being accumulators for $\mathrm{Cr}, \mathrm{Pb}$ and $\mathrm{Hg}$. These are the rape seed plant (Brassica napus Linn.), the water hyacinth (Eichhoria crassipes) and hydrilla (Hydrilla verticillata).

Coconut palm (Cocos nucifera L.), corn (Zea mays) and sunflower (Helianthus annus L.) can store up radioactive elements such as Caesium and Uranium. 
Common osier (Salix viminalis Linn.) and sunflower have also shown promise in their ability to amass hydrocarbons, as well as degrade PAHs in soils [15].

Sunflowers are also one of several flowers capable of accumulating heavy metals. Among the wildflowers there are a few which can trap multiple metals. Within the Brassicaceae family there are three such flowers: Arabidopsis bundles Cd, Fe and Zn, Thlapsi (Pb, Zn, Cd and Ni) and Brassica Rapa Sylvestris (Cd and Cr) [16].

Other flowers efficient in accumulating heavy metals, especially $\mathrm{Pb}, \mathrm{Cd}$ and $\mathrm{Zn}$, are Cistus salvifolius (Cistaceae), Aster (Asteraceae), Hypericum perforatum (Hypericaceae), Yarrow (Achillea millefolium) and Chives (Allium schoenoprasum). The last two are very effective accumulator for Cadmium.

Plants and wildflowers are not alone in their ability to potential uptake contaminants. Vetiver grass (Vetiveriazizanioides $L$. Nash) is also very effective (Figure 2). Although it has been used in Hong Kong for land protection and to mitigate soil erosion, it has potentials within the bioremediation field with a high tolerance to a range of trace elements such as As, $\mathrm{Cu}$ and $\mathrm{Cd}$ [17]. Other grasses worth of mention are Colonial Bentgrass (Agrostis castellana) which accumulates $\mathrm{As}, \mathrm{Pb}, \mathrm{Zn}, \mathrm{Mn}$ and $\mathrm{Al}$, for hydrocarbons rhizodegradation/accumulation the Buffalo grass (Buchloe dactyloides) and Bermuda grass, or lawn grass (Cynodon dactylon) have shown remarkable results in treating PAH in soil and they are also cost effective considering the low maintenance required [15].

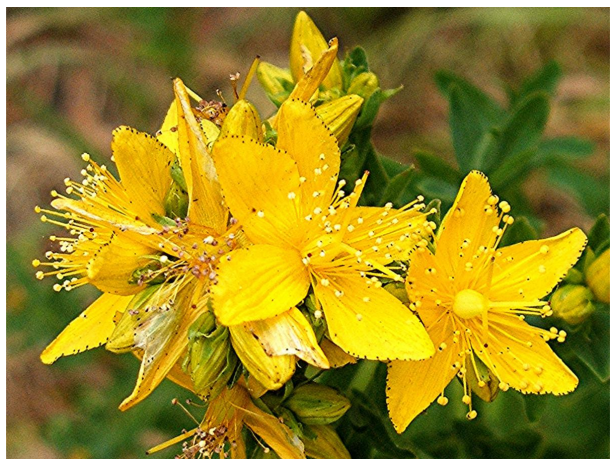

(a)

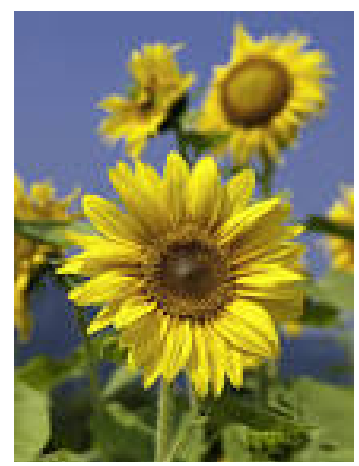

(b)

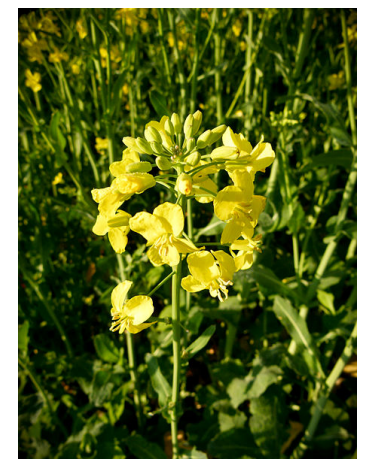

(c)

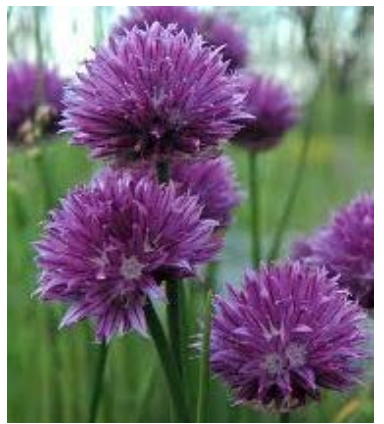

(d)

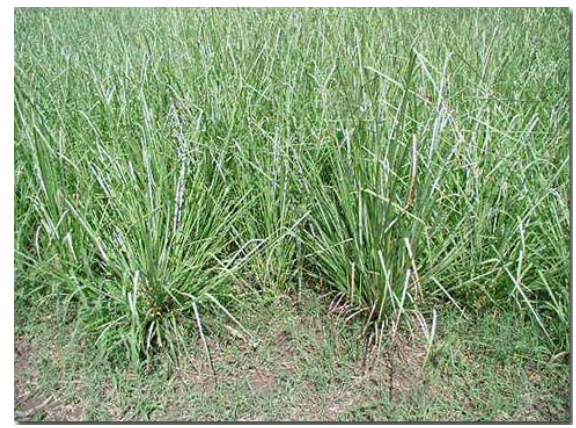

(e)

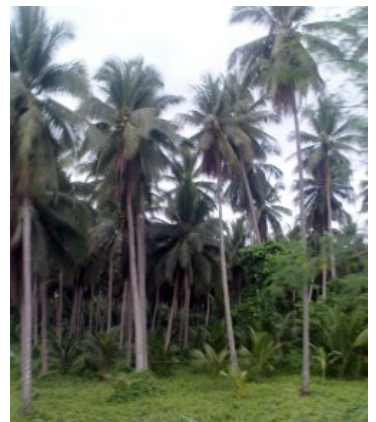

(f)

Figure 2. (a) Hypercum perforatum, (b) Sunflower, (c) Rape seed plant, (d) Chives, (e) Vetiver grass and (f) Coconut palms.

\section{Conclusions}

PAHs and heavy metals are pervasive in Hong Kong soils. Although the worse contamination is found in urban and orchard soils, other areas such as rural and forest soils are also affected [6].

The reason for soil contamination is without doubt linked to anthropogenic activities that have been increasingly sharp during recent years. The misuse of urban and rural soil, combined with the lenient enforcement of environmental policies, has generated PAH and heavy metal contamination in cities likes Hong Kong, posing a serious threat to their inhabitants.

A few techniques commonly used to clear contaminated soil can be so aggressive that they can also damage the organic material present within it. Moreover, some of them are fruitless when faced with certain types of contaminants. 
The use of plants and wildflowers instead can be seen as a greener and gentler way to treat this issue. However, there are multiple factors that might influence the final result, such as the extent of the soil contamination, the availability and accessibility of contaminants and the ability of the plant and its associated microorganisms to intercept, absorb, accumulate and/or degrade the contaminants [18].

As this field expands with time, it is important to understand whether or not it can be used effectively. If we consider urban soil, wildflowers reduce the amount of contaminants and at the same time, provide a pleasing visual to the public. This method, therefore, can be deemed suitable to clean up recreational areas, parks and other such urban spaces.

More aggressive methods would probably be more suitable for e-waste and industrial zones. Phytoremediation requires time and may not be appropriate if areas affected by heavy contamination need to be cleaned up.

The depth at which the contaminants are in the ground also poses a challenge. If the depth is so great that roots cannot reach the heavy metals and PAHs, they will not extract from the soil. Another concern is how to safely dispose the plants, which after phytoaccumulation, are holding all the pollutants. Burning them would release heavy metals back into the ecosystem and if they are to be stored, it must be done properly.

In orchard and agricultural fields, the use of certain varieties of plants and vegetables can reduce the amount of contaminants in the soil. Many of them are edible but after accumulating pollutants, they can no longer be sold in the market. This problem can adversely affect the economy of local farmers, as they will temporarily lose part of their income.

Future research will probably lead to a more effective use of phytoremediation over large-scale areas and be more feasible, especially for agricultural lands.

Recent studies are also focusing their attention on harvesting only roots as a method to maximise the removal of soil pollutants as the roots sequester the majority of the contaminants taken up in most plants [19].

Despite its constraints, phytoremediation has potential and must be considered as a green option for the clean-up of urban and other contaminated soils. It is a non-invasive technique which has proved to be also cheaper than other conventional methods. It is worth exploring and implementing in cities such as Hong Kong and in many other environments.

\section{Acknowledgements}

The author wishes to thank Judy Wu and Cristina Pandolfo for their contributions to this paper.

\section{References}

[1] Li, X., Lee, S., Wong, S., Shi, W.Z. and Thornton, I. (2004) The Study of Metal Contamination in Urban Soils of Hong Kong Using a GIS-Based Approach. Environmental Pollution, 129, 113-124. http://dx.doi.org/10.1016/j.envpol.2003.09.030

[2] Girard, J.E. (2005) Principles of Environmental Chemistry. Jones and Bartlett Publishers, Inc., Burlington, 47-53.

[3] Su, C., Jiang, L. and Zhang, W. (2014) A Review on Heavy Metal Contamination in the Soil Worldwide: Situation, Impact and Remediation Techniques. Environmental Skeptics and Critics, 3, 24-38.

[4] Lai, K.W. (2011) Geotechnical Properties of Colluvial and Alluvial Deposits in Hong Kong. The 5th Cross-Trait Conference on Structural and Geotechnical Engineering (SGE-5), Hong Kong, 13-15 July 2011, 735-744.

[5] Jim, C.Y. (1998) Urban Soil Characteristics and Limitations for Landscape Planting in Hong Kong. Landscape and Urban Planning, 40, 235-249. http://dx.doi.org/10.1016/S0169-2046(97)00117-5

[6] Chen, T.B., Wong, J.W.C., Zhou, H.Y. and Wong, M.H. (1997) Assessment of Trace Metal Distribution and Contamination in Surface Soils of Hong Kong. Environmental Pollution, 96, 61-68. http://dx.doi.org/10.1016/S0269-7491(97)00003-1

[7] Wong, M.H. (1987) A Review on Lead Contamination of Hong Kong’s Environment. In: Hutchinson, T.C. and Meema, K.M., Eds., Lead, Mercury, Cadmium and Arsenic in the Environment, Chapter 14, 217-223.

[8] Chung, M.K., Hu, R., Cheung, K.C. and Wong, M.H. (2007) Pollutants in Hong Kong Soils: Polycyclic Aromatic Hydrocarbons. Chemosphere, 67, 464-473. http://dx.doi.org/10.1016/j.chemosphere.2006.09.062

[9] Man, Y.B., Kang, Y., Wang, H.S., Lau, W., Li, H., Sun, X.L., Giesy, J.P., Chow, K.L. and Wong, M.H. (2013) Cancer risk Assessments of Hong Kong Soils Contaminated by Polycyclic Aromatic Hydrocarbons. Journal of Hazardous Materials, 261, 770-776. http://dx.doi.org/10.1016/j.jhazmat.2012.11.067

[10] Environmental Protection Department (2011) Practice Guide for Investigation and Remediation of Contaminated Land. 
[11] Bento, F.M., Camargo, F.A.O., Okeke, B.C. and Frankenberger, W.T. (2005) Comparative Bioremediation of Soils Contaminated with Diesel Oil by Natural Attenuation, Biostimulation and Bioaugmentation. Bioresource Technology, 96, 1049-1055. http://dx.doi.org/10.1016/j.biortech.2004.09.008

[12] Raskin, I., Smith, R.D. and Salt, D.E. (1997) Phytoremediation of Metals: Using Plants to Remove Pollutants from the Environment. Current Opinion in Biotechnology, 8, 221-226. http://dx.doi.org/10.1016/S0958-1669(97)80106-1

[13] Prasad, M.N.V. and de Oliveira Freitas, H.M. (2003) Metal Hyperaccumulator in Plants-Biodiversity Prospecting for Phytoremediation Technology. Electronic Journal of Biotechnology, 6, 285-321. http://dx.doi.org/10.2225/vol6-issue3-fulltext-6

[14] Khokhar, A.L., Rajput, M.T., Ahmed, B. and Tahir, S.S. (2012) Checklist of Flowering Plants Used in Phytoremediation Found in Sindh, Pakistan. Sindh University Research Journal (Science Series), 44, 497-500.

[15] McCutcheon, S.C. and Schnoor, J.L. (2003) Phytoremediation, Transformation and Control of Contaminants. Wiley, New York.

[16] Pandolfo, C. (2012) La fitorimediazione e i fiori spontanei. Università degli Studi di Catania, Facoltà di Agraria. http://dryades.altervista.org/La_fitorimediazione_e_i_fiori_spontanei_-_Dott.ssa_Cristina_Pandolfo.pdf

[17] Khan, A.G. (2003) Vetiver Grass as an Ideal Phytosymbiont for Glomalian Fungi for Ecological Restoration of Heavy Metal Contaminated Derelict Land. Proceedings of the 3rd International Conference on Vetiver and Exhibition, Guangzhou, October 2003, 466-474.

[18] Vangronsled, J., Herzig, R., Weyens, N., Boulet, J., Adriaensen, K., Ruttens, A., Thewys, T., Vassilev, A., Meers, E., Nehnevajova, E., van der Lelie, D. and Mench, M. (2009) Phytoremediation of Contaminated Soils and Groundwater: Lessons from the Field. Environmental Science and Pollution Research, 16, 765-794. http://dx.doi.org/10.1007/s11356-009-0213-6

[19] Negri, M.C., Hinchman, R.R. and Gatliff, E.G. (1996) Phytoremediation: Using Green Plants to Clean up Contaminated Soil, Groundwater and Wastewater. Proceedings of the International Topical Meeting on Nuclear and Hazardous Waste Management, Spectrum 96, Seattle, 18-23 August 1996, 1-10. 
Scientific Research Publishing (SCIRP) is one of the largest Open Access journal publishers. It is currently publishing more than 200 open access, online, peer-reviewed journals covering a wide range of academic disciplines. SCIRP serves the worldwide academic communities and contributes to the progress and application of science with its publication.

Other selected journals from SCIRP are listed as below. Submit your manuscript to us via either submit@scirp.org or Online Submission Portal.
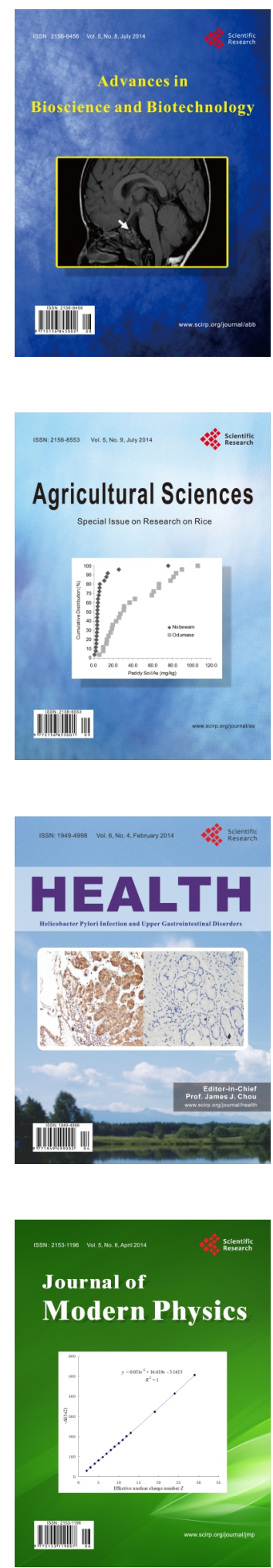
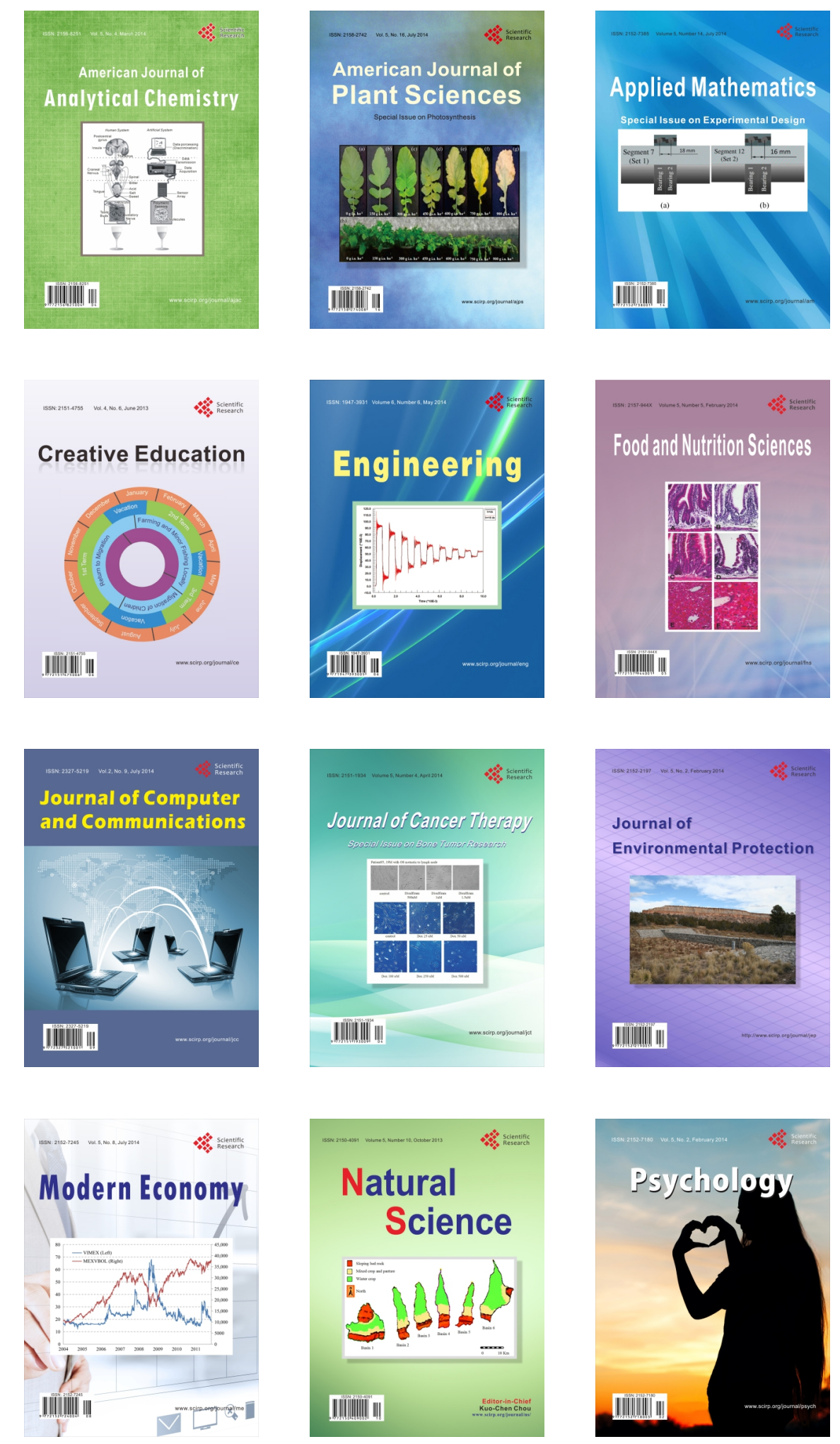